\title{
The role of cytokines in acute myeloid leukemia: A systematic review
}

\author{
Tomas Kupsa ${ }^{\mathrm{a}, \mathrm{b}}$, Jan Milos Horacek ${ }^{\mathrm{a}, \mathrm{b}}$, Ladislav Jebavy ${ }^{\mathrm{a}, \mathrm{b}}$
}

\begin{abstract}
Background. Acute myeloid leukemia (AML) shows a high degree of heterogeneity owing to a variety of mutations and the mechanisms of leukemogenesis. This heterogeneity is often not reflected in standard treatment approaches which while providing predictable outcomes in the majority of patients fail in particular cases even with high-dose multiagent chemotherapy regimens. Further, the unselective effect of chemotherapy leads to high treatment-related toxicity and the enormous risk of infection during prolonged pancytopenia, preventing further dose escalation.

Objectives. Cytokines play a role in leukemogenesis, AML cell persistence and treatment outcome. In this review we highlight cytokine dependent mechanisms essential for AML cell survival and the role of single cytokines in leukemogenesis and allogeneic transplantation-related phenomena. Cytokine-related mechanisms of leukemogenesis, AML cell persistence and resistance to chemotherapy are complex. Modulation of the cytokine network can disrupt signalling pathway activation and overcome the high resistance to treatment. It may also increase the selectivity of AML treatment, reduce the overall treatment-related toxicity and improve outcomes of AML treatment in all age groups of patients.

Conclusions. This review provides a deeper insight into these processes with focus on the most vulnerable step. Special attention is paid to the possibility of selective influence on defined cell populations for therapeutic target. We believe that modulating cytokine-dependent processes in AML is an approach that could be included in standard chemotherapeutic regimens for improving overall treatment outcome.
\end{abstract}

Key words: AML, cytokines, leukemogenesis, prognosis, treatment approaches

Received: August 14, 2012; Accepted: December 3, 2012; Available online: December 6, 2012 http://dx.doi.org/10.5507/bp.2012.108

${ }^{a}$ Department of Internal Medicine, University of Defence, Faculty of Military Health Sciences in Hradec Kralove, Czech Republic ${ }^{b} 4^{\text {th }}$ Department of Internal Medicine - Hematology, Faculty of Medicine, Charles University in Prague, University Hospital in Hradec Kralove Corresponding author: Tomas Kupsa, e-mail: Tomas.Kupsa@seznam.cz

\section{INTRODUCTION}

AML is an aggressive disorder characterized by accumulation of immature malignant cells in bone marrow. Most adult patients with AML die from the disease. Even high-dose multi-agent chemotherapy and allogeneic stem cell transplantation often fail to prevent relapses. The heterogeneous phenotype of AML is based on cytogenetic mutations and molecular aberrations. Based on analysing large cohorts of patients, most have a defined prognostic significance ${ }^{1-5}$ with direct impact on treatment strategy. Progress in molecular methods is enabling more accurate prediction of patient outcome ${ }^{6}$ and providing useful MRD markers. Nevertheless, prognostic factors in AML are heterogeneous, and new ones are still likely to be found. Cytokines are soluble molecules carrying specific information for target cells. Acting through a surface receptor, they provide target cells with specific information about conditions inside the organism, and cause a specific response. The response may be, e.g. stimulating and activating in the case of inflammation or in the case of tissue damage, causing proliferation or apoptosis. Under abnormal conditions, this physiological role of cytokines is maladaptive. The influence of inflammation and altered cytokine signalling on oncogenesis, leading to tumour progression, has been documented $\mathrm{d}^{7,8}$, and is still a site of interest in several solid tumors ${ }^{9-11}$. Blood cells and their marrow- based progenitors are exquisitely responsive to their environment, and cytokines are an essential part of it. On binding to cytokine receptor, signal transduction pathways (STP) are activated. Abnormalities in signalling through STP are common in AML. In fact, autonomous cell proliferation during leukemogenesis is unlikely without altered STP activation. The frequency of STP activation in AML (ref. ${ }^{12}$ ) exceeds the frequency of mutations and genetic alterations in receptors or STP components ${ }^{13,14}$, suggesting that STP activation, triggered by cytokines binding to unmutated receptors, is a frequent event in leukemia development and should not be underestimated. Aberrant cytokine levels in AML and abnormal responsiveness to them is well-documented. The overexpression of cytokines in leukemia patients declines in complete remission ${ }^{15,16}$, suggesting that these events are dependent on AML activity, possibly due to autonomous blast cytokine secretion. Several factors have been reported to contribute to the growth advantage of the malignant clone, including the autonomous proliferation and autocrine production of cytokines by these cells, such as G-CSF, GM-CSF, IL-1 and IL-6 (ref. ${ }^{17-19}$ ). Based on attempts to further classify AML patients according to cell response to changing levels of chemokines $^{20}$, new classification schemes of AML have been developed. These also reflect the ability of AML cells to stimulate angiogenesis or chemotaxis. It remains to establish whether this kind of classification for different cytokine families, especially interleukins, is of prognostic 
value in AML risk stratification. This would provide us with deeper insight into contributing factors triggering blast cell proliferation, migration and tissue infiltration as these are the basic questions in AML cell biology with possible treatment consequences.

\section{CYTOKINES IN AML PROLIFERATION AND PROGNOSIS}

Based on their biological effects, cytokines may be divided into six major families ${ }^{21}$ - interleukins (IL), chemokines, interferons (INF), tumor necrosis factors (TNF), growth factors of hematopoiesis and transforming growth factor- $\beta$ (TGF- $\beta$ ) family members. For further details see Table 1.

Cytokine levels at AML diagnosis are aberrant and normalize in remission ${ }^{15,16}$. Levels of circulating cytokines and changes in patient outcome have been the subject of numerous studies. It has been reported that cytokine stimulation causes abnormal responsiveness in leukemic blasts and that leukemic blasts are often a source of cytokine or chemokine production possibly triggering autocrine and paracrine loop activation.
There are a large number of cytokines circulating in the plasma with various possible effects on AML blast cell proliferation. The most troublesome for assessing their effects is that cytokines are produced and act simultaneously, with a partially overlapping spectrum of biological effects due to frequent receptor sharing. This makes it difficult to predict the relationship between leukemogenesis contribution and individual cytokine levels.

The IL-1, IL-2 and $\beta$-chemokine of CC subgroup CCL3 (CC-ligand-3) have been shown to stimulate leukemic cell proliferation ${ }^{22-25}$. To further assess the role of several single cytokines on the proliferation of patient-derived AML cells, a cytokine-induced proliferation study was performed $^{26}$. In the total study population, only autonomous blast cell proliferation was a significant predictor for prognosis from the multivariate analysis. Assuming that especially for the intermediate-risk AML patients, a further prognostic classification would have significant benefit, the AML blasts of FLT3-ITD (FMS-like tyrosine kinase 3 internal tandem duplications) negative patients with intermediate risk cytogenetics were further studied. The strongest responses to cytokine stimulation were observed for IL-3, GM-CSF and G-CSF, but only the responses to IL- $1 \alpha$ and M-CSF were found to be predictive

Table 1. Basic classification of cytokines.

\begin{tabular}{|c|c|c|}
\hline Cytokine family & Functional subgroups & Physiologic effect \\
\hline \multirow[t]{3}{*}{ Interleukins } & IL-3, IL-7, Flt3-ligand & - stimulate hematopoiesis \\
\hline & IL-1, IL-6 & - pluripotent, inflammatory \\
\hline & IL-2, IL-4, IL-5, IL-12, IL-13 & - regulate $\mathrm{T}$ and $\mathrm{B}$ cell cooperation \\
\hline \multirow[t]{3}{*}{ Chemokines } & $\alpha: \mathrm{CXC}$ & $\begin{array}{l}\text { - regulate migration of granulocytes and lymphocytes } \\
\text { - promote angiogenesis and inflammation }\end{array}$ \\
\hline & $\beta: \mathrm{CC}$ & $\begin{array}{l}\text { - regulate migration of monocytes } \\
\text { - enable medullar homing }\end{array}$ \\
\hline & $\gamma: \mathrm{C}, \delta: \mathrm{CX}_{3} \mathrm{C}$ & - regulate migration of lymphocytes \\
\hline \multirow[t]{2}{*}{ Interferons } & Type I: INF $\alpha, \beta, \omega$ & $\begin{array}{l}\text { - antiviral immunity } \\
\text { - anti-proliferative effect }\end{array}$ \\
\hline & Type II: INF $\gamma$ & $\begin{array}{l}\text { - antitumorous activity } \\
\text { - response to intracellular pathogens }\end{array}$ \\
\hline \multirow[t]{2}{*}{ Tumor necrosis factors } & TNF $\alpha:$ & $\begin{array}{l}\text { - pro-inflammatory pyrogenic } \\
\text { - activates non-specific immunity } \\
\text { - adhesive molecule expression on endothelial surface } \\
\text { - may cause apoptosis - } \\
\text { - overproduction causes SIRS }\end{array}$ \\
\hline & TNF $\beta$ : & - similar in effect, but produced by T- and B lymphocytes \\
\hline Colony Stimulating & G-CSF, GM-CSF, M-CSF & - stimulate proliferation and maturation of myeloid precursors \\
\hline Factors & $\begin{array}{l}\text { Erythropoietin } \\
\text { Thrombopoietin }\end{array}$ & \\
\hline TGF- $\beta$ & & $\begin{array}{l}\text { - stimulate growth of fibroblasts and extracellular matrix } \\
\text { production } \\
\text { - lead to MMPs inhibition }\end{array}$ \\
\hline
\end{tabular}


for therapeutic outcome. In this study, the response to IL-7, IL-11 and TNF- $\alpha$ could be interpreted as inhibition of AML blast cell proliferation. IL-7 is a major cytokine in lymphopoiesis and IL-11 plays a role particularly in thrombopoiesis, but the response to TNF- $\alpha$ stimulation in this study remains confusing. In a different study ${ }^{27}$, within AML and high risk myelodysplastic syndrome (MDS) patients, a close correlation between TNF- $\alpha$ level and leukocyte count was found. Lower TNF- $\alpha$ levels were associated with higher CR rates, better overall and event-free survival. Higher TNF- $\alpha$ levels were statistically significant when leukocyte count was excluded from the models, confirming their predictive value for therapeutic outcomes. Higher serum TNF- $\alpha$ levels further correlated with higher levels of $\beta_{2}$-microglobuline, creatinine and alkaline phosphatase, and inversely with creatinine clearance and albumin levels. Higher TNF- $\alpha$ levels were also correlated with poorer performance, M4-M5 AML subtypes according to French-American-British (FAB) classification and the presence of infection.

Further, although the IL-3-receptor expression within the cytokine-induced proliferation study was not measured and thus the data on IL-3R density are not available, the non-significance of IL-3 stimulation response is an issue. As cytokine receptor expression is inducible ${ }^{21}$, we can expect sufficient expression of this receptor during the cytokine induced 7 day proliferation assay ${ }^{26}$. The density of IL-3R- $\alpha$ subunits (CD 123) on AML blasts was found to be an independent risk factor for AML (ref. ${ }^{28}$ ). At the clinical level, a significant correlation between the level of IL-3R expression and the number of leukemic blasts at diagnosis was observed. Patients exhibiting elevated IL-3R levels had lower complete remission rates and survival duration than those with normal IL-3R levels. Following IL-3R stimulation, various STPs, including MAPK (mitogen activated protein kinase) MEK/ERK (ref. ${ }^{29-31}$ ), phosphatidylinositol 3-kinase (PI3K) (ref. $\left.{ }^{32,33}\right)$, protein kinase A (PAK) $\left(\right.$ ref. $\left.{ }^{34}\right)$ and signal transducer and activator of transcription 5 (STAT-5) are activated. IL-3 mediated activation of STAT-5 up-regulates the antiapoptotic protein Bcl- $\mathrm{X}_{\mathrm{L}}$ and promotes cell survival ${ }^{35}$. STAT-5 activation is required for the maintenance and expansion of primitive hematopoietic stem and progenitor cells, in both normal and leukemic hematopoiesis ${ }^{36}$. These data demonstrate the ability of IL-3 to activate various STPs. Proteomic studies on JAK/STAT, RAS/Raf/MEK/ERK and PI3K/ AKT pathways revealed, that the number of activated STPs correlates inversely with patient outcome ${ }^{37}$. As there were patient samples with either no or all STPs activated, extensive cross-talk and cross-activation between these pathways is probable. Deregulated STP signalling contributes to the proliferative advantage of the leukemic blasts and the high degree of various STPs activation is a crucial step in leukemogenesis. Of the STPs mentioned above, STAT-5 appears to be the most interesting. STAT5 activation is not restricted to IL-3R downstream processes. STAT-5 (and MAPK) are constitutively activated in FLT3-ITD positive AML, and are sufficient to promote IL-3-independent proliferation of AML cells ${ }^{38}$. In contrast to wild type FLT3 receptor, FLT3-ITD is a potent STAT-
5 activator. The juxtamembrane STAT-5 docking sites and role of mutation of these sites have been described ${ }^{39}$. Activated STAT-5 up-regulates MCL-1 (myeloid cell leukemia-1), which is an essential survival factor for both normal and leukemic hematopoiesis. STAT-5 inhibition then completely abrogates this process ${ }^{40}$. Futhermore, in chronic myeloid leukemia, the BCR-ABL kinase activity also activates STAT-5 and causes IL-3 independent expression of antiapoptotic protein $\mathrm{Bcl}_{\mathrm{L}}\left(\mathrm{ref}^{41}{ }^{4}\right.$ ) The importance of STAT-5 activation is also documented for leukemic stem cells (LSCs) or leukemia initiating cells (LICs). LSCs are a rare population of cells with a specific immunophenotype ${ }^{42}$, capable of high persistence, selfrenewal, proliferation and differentiation into malignant blasts. In a study designed to demonstrate the functional heterogeneity of LSCs and the role of STAT5 activation, highly active STAT-5 signalling was associated with coexpression of oncogenes of different molecular subgroups in LSCs and in the sample of 201 patients, it was restricted to those with the poorest prognosis ${ }^{43}$.

Given its influence on cell proliferation (and leukemogenesis), it follows that STAT-5 activation needs to be regulated properly. To provide greater insight into complex processes affecting the degree of STAT-5 activation, the murine IL-3 dependent BaF3 cell line (BaF3 cells lack expression of gp 130, a common receptor subunit of the class I - IL-6 subfamily cytokine receptor, for further details see below) was investigated. RhoH is a constitutively active member of the family of Rho GTPases. Its expression is restricted to the haematopoietic lineage where it serves as a positive regulator for T-cell selection and mast cell function and, as a negative regulator for growth-related functions in other lineages. $\mathrm{RhoH}$ regulates IL-3-induced signalling through modulation of the activity of STAT proteins ${ }^{44}$. The overexpression of RhoH decreases IL3-induced proliferation and the activity of STAT-5. The surface expression level of the IL-3 receptor $\alpha$-chain (CD123) is inversely correlated with the expression levels of RhoH. In RhoH-deficient cells, the STAT-5-dependent gene for interferon regulatory factor-1 (IRF-1) was up-regulated, leading to an up-regulation of CD 123 expression. Interestingly, only BaF3 cells that overexpressed $\mathrm{RhoH}$ were able to activate STAT1 after stimulation with IL-3. Activation of STAT-1 is known to coincide with cell cycle arrest or apoptosis and the STAT-1 dependent cell cycle inhibitors p21Cip1 and p27Kip1 were shown to be upregulated due to $\mathrm{RhoH}$ overexpression. As mentioned, elevated CD123 expression in AML patients contributes to increased proliferation of leukemic blasts, hyper-activation of STAT-5 and poor prognosis ${ }^{28}$. Low expression levels of RhoH were also described as another factor in poor patient prognosis ${ }^{45}$. These data demonstrate that these two findings might be connected.

\section{Interleukin 6}

IL-6 has diverse effects in malignant cell biology, with proven prognostic impact in diffuse large-cell lymphoma and chronic lymphocytic leukemia ${ }^{46,47}$. IL-6 is a pleiotropic cytokine that can be constitutively expressed in AML cells $^{48}$, IL-6 levels are markedly increased in AML/MDS 
patients ${ }^{16}$. Activation of IL-6 signal transduction involves dimerization of IL-6 receptor gp130 subunit, consequently recruitment of gp130-associated protein-tyrosine kinases Jak1, Jak2, and Tyk2 and tyrosine phosphorylation of STAT-3, to a lesser extent STAT-1 $\left(\right.$ ref. $^{49}$ ). At least two other STPs (ERK and PI3K) are also activated by IL-6 (ref. $^{50-52}$ ). STAT-3 plays a key role in G1- to S-phase cellcycle transition through the up-regulation of cyclins D2, D3, A, and cdc25A and concomitant down-regulation of p21 and p27 (ref. ${ }^{53}$ ). Constitutive STAT-3 activation has been demonstrated in AML and is described in about 20\% of patients ${ }^{54}$. It was later shown that STAT-3 is constitutively phosphorylated on Tyr705 and Ser727, which could be not further up-regulated by treatment with IL-6. AML cells with constitutive STAT-3 activation also secreted high levels of IL-6 protein, suggesting probable Jak/STAT pathway stimulation in an autocrine or paracrine manner, or both ${ }^{55}$. This might lead to a growth advantage of the malignant clone, although this has not been proved. In a study on 75 patients IL-6 serum levels were not found to be predictive for CR rates, survival or event free survival ${ }^{27}$. Whether this was caused by STAT-1 activation or higher TGF- $\beta 1$ serum levels remains unclear. The main function of TGF- $\beta 1$ in hematopoietic cells is to regulate cell proliferation by inducing growth arrest in the G0/G1 phase of the cell cycle ${ }^{56,57}$. TGF- $\beta 1$ is a member of the TGF superfamily of proteins. TGF-1 exerts its effects by binding to its receptor (TGF-receptor type II, TGF-RII), which results in recruitment of a second receptor chain (TGFreceptor type I, TGF-RI) $\left(\right.$ ref $\left.^{58}\right)$. Hetero-dimerization of the receptor chains leads to phosphorylation of TGFRI, resulting in activation of its intrinsic kinase activity. SMAD (Sma- and Mad related) proteins 2 and 3 are subsequently phosphorylated by the activated TGF-RI, leading to their association with SMAD4 and translocation to the nucleus, where the SMAD2, -3, -4 complex initiates gene transcription of TGF-1-responsive genes ${ }^{59}$. To explore cross-talk between the IL- 6 and TGF-1 pathways in AML blast cells, the effect of TGF-1 pre-treatment on IL-6-induced STAT-3 tyrosine phosphorylation was studied. In $10 \%$ ( 4 out of 40 ) of AML patients, a significant reduction in IL- 6 mediated STAT-3 tyrosine phosphorylation after TGF- $\beta 1$ pre-treatment was observed. Measured by means of SMAD3 translocation, TGF- $\beta 1$ affected all of the AML cases studied, but only reduced IL-6-mediated STAT-3 tyrosine phosphorylation after pretreatment with TGF- $\beta 1$ was associated with apoptosis ${ }^{60}$. In conclusion, although $10 \%(4 / 40)$ is a small percentage, at least these patients could benefit from TGF- $\beta 1$ treatment. Unfortunately, further specification of this group by cytogenetics or molecular genetics is not available.

\section{CHEMOKINES}

Chemokines form a cytokine family of soluble mediators with a molecular weight up to $10 \mathrm{kDa}$. Chemokines (the name of this group comes from origin chemotactic cytokines) help to regulate cell migration, are involved in angiogenesis, cellular growth control, inflammation response development and immunomodulation. All nuclear cells can produce chemokines, which is of major importance as all nuclear cells can take part in immune system activation. Chemokine secretion appears after prestimulation. There are four subgroups of chemokines distinguished according to the spacing of highly conserved cystein residues: $\mathrm{C}, \mathrm{CC}, \mathrm{CXC}, \mathrm{CX}_{3} \mathrm{C}$. With an overlapping spectrum of action and some kind of receptor nonspecifity, chemokines form a network redundant in count but this redundancy provides robust outputs of network activation $^{21,61-65}$. In a complex study by Bruserud, the effects of various chemokines on proliferation of patient-derived AML cells and constitutive chemokine release by primary AML cells have been investigated in vitro in AML cells derived from 68 consecutive patients ${ }^{20}$. Exogenous chemokines usually had no effect on AML blast cell proliferation, but having the hematopoietic growth factors (IL-3 + GM-CSF + stem cell factor - SCF) added to the cultures, proliferation in suspension cultures occurred and specific patient subsets were identified. In nearly one third of patients' AML cell samples, chemokine stimulation induced proliferation or led to divergent effects on proliferation. Further, the AML cells were found to release chemokines of homeostatic and inflammatory groups, and of both pro-angiogenic, with the highest levels detected for CXCL8, and the anti-angiogenic group. In contrast, some chemokines, including CXCL12 (acting on CXCR4, for more information see below) were not detected in any, or only in a few patients. The influence of chemokine release on chemotaxis was also studied. Although the patterns of chemokine release in AML cell samples differed, in the presence of chemokine release, chemotaxis was stimulated as a whole, with no detectable specific effect on various T-cell subsets. Based on experimental data, the patients were divided according to hierarchical clustering into subgroups for chemokine induced proliferation, autonomous chemokine secretion and chemotaxis activation. There was a significant correlation between no detectable in vitro proliferation and low chemokine release, showing that chemokines are excreted at higher rates by proliferating cells. None of these subgroups correlated with known prognostic factors, e.g. cytogenetics of FLT3 mutation status, demonstrating the heterogeneity of growth factors-dependent AML cells.

Besides the descriptive outcomes of the study mentioned above, several chemokine characteristics are noteworthy. The chemokine receptor/ligand interactions orchestrate the migration of cells to peripheral tissues ${ }^{66}$. As CXCL8 is usually secreted in highest levels, serum CXCL8 seems to partly reflect the AML cell burden ${ }^{67}$. The release of angiogenic stimuli from the AML cells is accelerated in hypoxia. In a hypoxic environment, the hypoxia inducible factor $1 \alpha(\mathrm{HIF}-1 \alpha)$ expression by AML cells is increased, leading to up-regulation of angiogenesis-related genes and angioregulatory cytokine expression ${ }^{68}$. AML cells cultured in vitro with $1 \% \mathrm{O}_{2}$ showed increased release of several CCL (CCL 3,4,5,7,8) and CXCL (CXCL1 and proangiogenic CXCL8) chemokines, vascular endothelial growth factor (VEGF) was also secreted at higher rates, compared to the same samples cultured at $21 \% \mathrm{O}_{2}$. The 
wide variation in cytokine expression between patients, observed in previous studies, persisted. The angiogenic effect of AML cells is, except for cytokines, also mediated by angiopoietin-1 (Ang-1) and by the matrix metalloproteinases (MMPs). Ang-1 is an AML cell constitutively released agonist on Tie-2 receptor with various interactions and possible therapeutic influence of this system ${ }^{69}$. MMPs are zinc-dependent endopeptidases able to degrade all components of the extracellular matrix (ECM). The ECM cleavage leads to removing physical barriers and prepares a new space for angiogenesis. The AML cells often show constitutive release of several MMPs together with proangiogenic cytokines, which rapidly leads to angiogenesis and possibly facilitates extramedullar spread of the AML $\left(\right.$ ref. $\left.^{70}\right)$.

\section{CXCL12/CXCR4 interaction in AML}

The best investigated single chemokine (not only in AML) is CXCL12. CXCL12 (often called stromal-derived factor $1 \alpha, \operatorname{SDF}-1 \alpha$ ) is a homeostatic chemokine constitutively secreted by marrow stromal cells. SDF- $1 \alpha$ binds to CXCR4. This interaction allows it to retain hematopoietic progenitors and leukemia cells inside the bone marrow and allows a high persistence of leukemia cells in the bone marrow. Binding of SDF- $1 \alpha$ to CXCR4 leads to receptor phosphorylation ${ }^{71}$, triggering prolonged activation of ERK and PI3K pathways ${ }^{72}$, which promotes (leukemia) cell survival ${ }^{73,74}$. The increased CXCR4 expression on the AML cells is an independent prognostic factor and a predictor of poor outcome in AML regardless of FLT3 mutation status ${ }^{75,76}$, but if the FLT3 is mutated, the CXCR4 expression is further enhanced ${ }^{77}$. Further studies revealed that SDF-1 $\alpha$ increases human ether-à-go-go related gene 1 (hERG1) $\mathrm{K}(+)$ channel expression in a dose dependent manner. SDF-1 $\alpha$ further increases expression of several genes including beta-catenin, cyclin D1 and cmyc, which is abolished when the hERG1 $\mathrm{K}(+)$ channels are blocked ${ }^{78}$. Here the possibilities of pharmacologic interaction become obvious. The SDF- $1 \alpha$ analogue AMD 3100 , known as plerixafor, is used in mobilizing normal progenitor cells ${ }^{79-80}$. Various SDF-1 $\alpha$ antagonists have been investigated. The polypeptide RCP168 seems to have strong antagonistic effect on the stromal cell-induced chemotaxis of leukemic cells. Furthermore, RCP168 blocked the binding of anti-CXCR4 monoclonal antibody 12G5 to surface CXCR4 in a concentration-dependent manner and inhibited SDF-1alpha-induced AKT and extracellular signal-regulated kinase phosphorylation ${ }^{81}$. Equivalent results were obtained with the small-molecule CXCR4 inhibitor AMD3465, a second generation CXCR4 inhibitor. AMD 3465 antagonized SDF-1 $\alpha$ and stroma-induced chemotaxis and suppressed stroma activated PI3K/AKT and MEK/ERK pathways, which effectively mobilized leukemia cells and stem cells into circulation and enhanced the sensitivity to chemotherapy or FLT3-inhibitor-induced cell death ${ }^{82}$. One more candidate with possible treatment consequences is E-4031, which can induce G0/G1 arrest, impair SDF-1 $\alpha$ induced proliferation or even induce apoptosis of AML cells ${ }^{78}$. From the above data, it is obvious that SDF-1 $\alpha / \mathrm{CXCR} 4$ interaction plays a key role in
AML development and therapeutic outcome. Modulating this interaction is a possible therapeutic approach. As the SDF- $1 \alpha$ receptor inhibition sensitizes the AML cells to chemotherapy, it is presumed to reach either standard outcomes with less intense chemotherapy and decreased toxicity, or even better outcomes without further damaging the patients by more aggressive treatment regimens. By far the most important advantage of this possible approach is the ubiquitous expression of CXCR4 in cells populating bone marrow, which would allow us to use this strategy in various haematological malignancies ${ }^{83,84}$.

\section{CYTOKINES IN ALLOGENEIC BONE MARROW TRANSPLANTATION}

Bone marrow transplantation (BMT) is a sophisticated procedure of replacing the patient's hematopoiesis by donor graft. The process of engraftment is substantially dependent on graft pluripotent cell stimulation by various cytokines and the repopulation of bone marrow. It also assumes sufficiently mature cell production, as well as normal hematopoiesis, is possible due to proper cytokine interplay. The aim of further cytokine level study in pre- and post-transplant period is to recognize groups of patients with either better outcome and lower risk of complications, or higher risk groups in terms of graft rejection or GvHD development. The cytokines are abundant and functionally diverse. For this reason, it is not easy to describe the integrative effect of cytokines on BMT outcome. According to pre-transplant cytokine profile investigations, the cytokine profiles of patients undergoing BMT differ from each other, and all differ from healthy controls, although all patients achieved complete remission. Briefly, three subgroups of patients according to hierarchical clustering could be identified. These groups differed especially in the hepatocyte growth factor (HGF) and G-CSF levels. One of these groups, characterized by high levels of HGF and G-CSF, showed low early treatment-related mortality ${ }^{85}$.

Apropos allogeneic stem cell transplantation, a novel T-hepler lymphocyte subset called Th17, with distinct effects in allotransplanted patients, has been described ${ }^{86}$. This lymphocyte subset was shown to have an important role in GvHD development and AML relapse control. The Th17 cells preferably differentiate from $\mathrm{CD} 4{ }^{+} \mathrm{CD} 161^{+}$ T-cell subset, but there are probably more pathways possible $^{87,88}$. Th17 development seems to be dependent on IL-1 $\beta$ signalling, supported by IL-6 and IL-23 (ref. ${ }^{89}$ ), with a distinct role for TGF- $\beta$ ( ref. $^{90}$ ). AML cells can affect T-cell differentiation and Th17 development within the bone marrow through their release of IL-1 $\beta$, IL-6 (ref. ${ }^{91}$ ) and T-cell chemotactic cytokines ${ }^{20,92}$. Surprisingly, the levels of circulating Th17 cells were not confirmed to be increased in untreated AML patients ${ }^{93}$, which is in contrast to a previous study ${ }^{94}$, possibly due to different mean age of patients enrolled. On the other hand, Th17 cells are not depleted during conventional chemotherapy and circulating Th17 cells can be detected even in periods of severe chemotherapy-induced lymphopenia ${ }^{93}$, so that suf- 
ficient pre-transplant levels of Th17 cells may be expected. Th17 cells were not shown to have direct antileukemic effect in AML, but the Th17/Treg (T-regulatory cells) ratio seems to be important. Treg are immunosuppressive $\mathrm{CD} 4{ }^{+} \mathrm{CD} 25^{\mathrm{HIGH}}$ regulatory T-cells, high pre-treatment Treg levels or lower Th17/Treg ratio seem to be associated with adverse prognosis ${ }^{95}$. Pre-transplant targeting of Treg cells or affecting Th17/Treg ratio is then a possible strategy for reducing the overall risk of $\mathrm{AML}$ relapse ${ }^{96}$.

Th17-lymphocyte subset coordinates and regulates local inflammation through IL-17 release ${ }^{97}$. The biological function of Th17 in allotransplanted patients is to facilitate GvHD development. Genetic variants in the IL-23/ Th17 pathway, based on gene polymorphism, have influence on both infectious and immunological posttransplant complications ${ }^{98}$. Secondly, high levels of IL-17 during early posttransplant cytopenia were observed in patients who later developed acute GvHD (ref. ${ }^{99}$ ). This was quite a small study and hence the results should be interpreted with caution, but this observation supports the results of the previous study ${ }^{98}$ and highlights the role of IL-17 in GvHD development. Further, patients receiving higher dose Th17 cells in the bone marrow graft or a higher dose Tc17 cells in the PBSC graft exhibited increased incidence of acute GvHD. Increased levels of Th17 cells were also observed at the onset of acute GvHD and these levels normalized when patients responded to treatment ${ }^{100}$. However, the necessity of Th17 cells for GvHD development is not absolute in GvHD pathogenesis ${ }^{101}$, Th17 cells interact with other T-cell subsets and the relative importance of distinct Th subsets seems to differ between various organs, possibly due to organ-specific variation in the chemokine network and Th subsets-specific chemotactic receptor expression ${ }^{102,103}$. These observations suggest that Th17 cells are important in GvHD development. As the IL-17 itself has only minor anti-proliferative effect on AML blasts, which was observed only in a minority of patients ${ }^{93}$, its role seems to be initially in immunomodulation. The results mentioned above indicate, that Th17 cells enhancement should be considered at high risk of AML relapse with no clinical GvHD, whereas Th17 cells inhibition or depletion may be useful in treatment of excessive GvHD.

\section{CYTOKINES IN AML THERAPY}

The effects of various cytokines on AML cell proliferation and survival have been tested ${ }^{104}$. Logically, cytokines with major impact on AML cell proliferation or apoptosis are candidates for therapeutic administration. IL-2 and the IL-2 in combination with histamine dihydrochloride were tested in randomized maintenance therapy trials. IL-2 alone was not found to be an effective remission maintenance therapy for AML patients in first CR (ref. ${ }^{105}$ ). The combined immunotherapy of IL-2 with histamine dihydrochloride significantly improved leukemia free survival, but the overall survival was not improved ${ }^{106}$. The data of this study were later reassessed and the consistency and robustness of the study were confirmed.
Leukemia free survival was offered as an acceptable surrogate for overall survival ${ }^{107}$. The patients in these trials were randomized according to complete remission attainment or demographic parameters, not according to STP activation, cytokine receptor expression etc., which does not fully reflect the AML heterogeneity. The disclosure of exact STP activation or further molecular mechanisms at the time of therapy initiation is not routinely available. This seems to be the main disadvantage of cytokines usage in AML treatment. The high activity of the disease often calls for urgent treatment initiation, so that the usage of suitable cytokines in AML treatment is not possible earlier than during the consolidation phase, when each cytokine, even if leading to massive AML burden reduction, would have only narrow spectrum of use. In particular cases, the AML cell growth is independent upon cytokine stimulation $^{38}$. On the other hand, there are chemokine-mediated processes affecting all cells participating in hematopoiesis or immune response control, namely SDF-1 $\alpha$ / CXCR4 interaction in bone marrow populating cells or Th17 cell activity in immune response, GvHD development and relapse control. Inhibition of leukemia mediated angiogenesis or MMPs inhibition is a possible addition to treatment of extra-medullary spreading leukemias, which are difficult to treat, show inferior outcomes and occur more commonly after allogeneic stem cell transplantation, as the graft versus leukemia effect seems to be stronger in bone marrow than in the peripheral tissues ${ }^{108}$. Also some signalling pathways, for example STAT-5, have major impact on leukemia cell proliferation and are commonly activated in AML with various genetic alterations.

We do believe that various modulations of these interactions will find therapeutic application. There is still much to investigate and describe, until the cytokine network modulation or specific STPs inhibition become an integrated part of post-remission therapy but if successful, it would greatly improve AML therapy outcomes. While the standard chemotherapy regimens have reliable outcomes in the majority of cases ${ }^{96}$, cytokine network modulation would provide increased selectivity of treatment with the potential of further improvement in disease control and treatment-related toxicity reduction.

\section{CYTOKINE RECEPTORS AND THEIR PROGNOSTIC SIGNIFICANCE}

The prognosis of AML patient is based on the interaction of treatment, the ability of AML cell to survive, and factors like increased risk of infections and life threatening bleeding. The survivability depends on conditions triggering cell division or providing the cell with an antiapoptotic phenotype and hence drug resistance. Cytokines are involved in intercellular communication, capable of providing target cells with proliferation inducing signals and protect it against apoptosis. They act through binding to surface receptors, that, based on the structure and STP activation mechanisms, may be divided into different families $^{21,109}$. Class I hematopoietic cytokine receptors are multimolecular complexes of different receptor subunits 
$\alpha, \beta$ and $\chi$. According to transmembrane subunit, IL-2, erythropoietin receptor (EPOR), also called IL-3 and IL-6 subfamilies are distinguished. The IL-2 receptor subfamily is sharing $\chi_{C}(C D 132)$ subunit and binds IL-2, IL-4, IL-7, IL-9, IL-13, IL-15 and IL-21. The IL-3 receptor subfamily carries $\beta_{\mathrm{C}}(\mathrm{CD} 131)$ subunit and binds IL-3, IL-5, GM-CSF and EPO. The IL- 6 receptor subfamily is sharing $\beta$ chain gp130 (CD 130) and binds IL-6, IL-11, IL-27, leukemia inhibiting factor (LIF) and oncostatin M. Stimulated class I hematopoietic receptors cause JAK/STAT signalling pathways activation. Note that IL-3, affecting mostly myeloid progenitors, and IL-7, affecting mostly lymphoid progenitors, have receptors of different subfamilies. Class II hematopoietin receptors bind interferons $\alpha, \beta, \chi$ and IL-10. The class II hematopoietin receptors show structural similarity to class I hematopoietin receptors and are also coupled with JAK/STAT signalling transduction. The TNF superfamily of receptors and ligands comprises at least 30 receptors and 20 ligands. Signalling through TNF receptors may lead either to cell proliferation and inflammatory response, or may trigger apoptosis by receptor death domain activation. The chemokine receptors are G-protein coupled, bind chemokines with quite a high affinity and typical overlapping receptor specificity. The TGF- $\beta$ receptor family consists of seven type I and five type II receptors, that heterodimerize to form receptors for multiple TGF- $\beta$ family members. Further signalization is either SMAD dependent or independent.

In AML cell biology but not only in this disease, the receptor tyrosine kinase (RTKs) family is clinically most relevant at the moment. It comprises receptors vital for hematopoiesis and mature blood cell function. The two most important RTKs members in AML are c-Kit and FLT-3 receptor. Platelet derived growth factor receptor (PDGFR), anaplastic large cell lymphoma kinase (ALK), fibroblast growth factor (FGF) receptor, IL-1 receptor, and M-CSF receptor also belong to the RTKs family. RTKs are activated by ligand-induced receptor dimerization. The intracellular kinase domains then become activated and the receptor cytoplasmic tyrosin residues and other tethered substrates are phosphorylated ${ }^{110}$. Mutations of c-Kit and FLT-3 are often found in AML with normal cytogenetics. Mutations in the c-Kit and FLT-3 receptor provide AML cell with permanent proliferative signal, protection from apoptosis ${ }^{111,112}$, and negatively influence patient progno$\operatorname{sis}^{6,113}$. Specific inhibition of mutated tyrosinkinases is a possible therapeutic approach. Unfortunately the results are not convincing, probably due to a high degree of internal heterogenity ${ }^{114}$.

\section{QUALITY OF LIFE ASPECT}

AML is a serious, mostly lethal disease. It often appears unexpectedly and with serious symptoms and poor prognosis. Treatment consists of aggressive, often multiagent chemotherapy. Not unexpectedly, as the AML treatment is generally disease based, the quality of life aspect is often overlooked. From the onco-hematologic point of view, the ability to promote or arrest malignant cell proliferation is of paramount importance. However, from the patient point of view, quality of life is an important aspect, and crucial for compliance. Given the long duration of treatment with a high risk of fatal complications and uncertain outcome, this aspect should not be underestimated.

Cytokine levels are increased in AML/MDS patients, initiating a pro-inflammatory and pro-proliferative environment. Inflammation-associated symptoms such as fatigue and increased body temperature bear this out. Aberrant cytokine levels are responsible for these symptoms. The TNF- $\alpha$, IL-1 receptor antagonist and IL-6 levels were found to be related to ratings of fatigue while higher IL-6 levels were even associated with poorer executive functions before treatment. In both cases, these findings were not associated significantly with haemoglobin levels, which should be interpreted as evidence of the influence of a pro- inflammatory microenvironment ${ }^{115}$. On the other hand, higher IL- 8 was associated with better memory performance. There were 54 patients in this study, comprising both AML and MDS patients, but only 26 patients were reassessed after one month period, so that the follow-up is incomplete. When evaluated, the data available show that although the fatigue did worsen after therapy initiation, in general the treatment did not seem to have adverse effects on cognitive function. The overall quality of life was found to be acceptable but could be improved. This could also be an aspect in novel therapeutic approach evaluation. We believe that cytokine investigation will help us to define novel therapeutic approaches, allowing the treatment to be more accurate in targeting the origin of leukemogenesis, and will provide better outcomes and higher quality of life for AML patients.

\section{ABBREVIATIONS}

AML, Acute myeloid leukemia; CR, Complete remission; ERK, Extracellular signal regulated kinase; FLT3-ITD, FMS-like tyrosine kinase 3 internal tandem duplications; G-CSF, Granulocyte colony stimulating factor; GM-CSF, Granulocyte/macrophage colony stimulating factor; GvHD, Graft versus host disease; IL, Interleukin; LIC, Leukemia initiating cell; LSC, Leukemia stem cell; MAPK, Mitogen activated protein kinase; MMPs, Matrix metalloproteinases; MRD, Minimal residual disease; PAK, Protein kinase A; PI3K, Phosphatidylinositol 3-kinase; Raf; RAS activated factor; STP, Signal transduction pathway; STAT, Signal transducer and activator of transcription

\section{ACKNOWLEDGEMENT}

The work was supported by Specific research project "Analysis of defined prognostic factors in acute myeloid leukemia" (Faculty of Military Health Sciences in Hradec Kralove) and by a long-term organisation development plan 1011 (Faculty of Military Health Sciences in Hradec Kralove). 


\section{CONFLICT OF INTEREST STATEMENT}

Author's conflict of interest disclosure: None declared

\section{REFERENCES}

1. Keating MJ, Smith TL, Kantarjian H, Cork A, Walters R, Trujillo JM, McCredie KB, Gehan EA, Freireich EJ. Cytogenetic pattern in acute myelogenous leukemia: a major reproducible determinant of outcome. Leukemia 1988;2(7):403-12.

2. Fenaux P, Preudhomme C, Lai JL, Morel P, Beuscart R, Bauters F. Cytogenetics and their prognostic value in de novo acute myeloid leukaemia: a report on 283 cases. Br J Haematol 1989;73(1):61-7.

3. Bloomfield CD, Shuma C, Regal L, Philip PP, Hossfeld DK, Hagemeijer AM, Garson OM, Peterson BA, Sakurai M, Alimena G, Berger R, Rowley JD, Ruutu T, Mitelman F, Dewald GW, Swansbury J. Long-term survival of patients with acute myeloid leukemia: a third follow-up of the Fourth International Workshop on Chromosomes in Leukemia. Cancer 1997;80(11 Suppl):2191-8.

4. Byrd JC, Mrózek K, Dodge RK, Carroll AJ, Edwards CG, Arthur DC, Pettenati MJ, Patil SR, Rao KW, Watson MS, Koduru PR, Moore JO, Stone RM, Mayer RJ, Feldman EJ, Davey FR, Schiffer CA, Larson RA, Bloomfield CD. Pretreatment cytogenetic abnormalities are predictive of induction success, cumulative incidence of relapse, and overall survival in adult patients with de novo acute myeloid leukemia: results from Cancer and Leukemia Group B (CALGB 8461). Blood 2002;100(13):4325-36.

5. Grimwade D, Walker $H$, Harrison $G$, Oliver F, Chatters $S$, Harrison $\mathrm{CJ}$, Wheatley K, Burnett AK, Goldstone $\mathrm{AH}$. The predictive value of hierarchical cytogenetic classification in older adults with acute myeloid leukemia (AML): analysis of 1065 patients entered into the United Kingdom Medical Research Council AML11 trial. Blood 2001;98(5):1312-20.

6. Schlenk RF, Döhner K, Krauter J, Fröhling S, Corbacioglu A, Bullinger L, Habdank M, Späth D, Morgan M, Benner A, Schlegelberger B, Heil G, Ganser A, Döhner H. Mutations and Treatment Outcome in Cytogenetically Normal Acute Myeloid Leukemia. N Eng J Med 2008;358(1):1909-18.

7. Coussens LM, Werb Z. Inflammation and cancer. Nature 2002 ; 420(6917):860-7.

8. Balkwill F, Mantovani A. Inflammation and cancer: back to Virchow? Lancet 2001;357(9255):539-45.

9. Zeh HJ, Winikoff $S$, Landsittel DP, Gorelik E, Marrangoni AM, Velikokhatnaya L, Winans MT, Lee K, Moser A, Bartlett D, Lotze MT, Siegfried JM, Whitcomb D, Papacristou G, Slivka A, Bigbee WL, Lokshin AE. Multianalyte profiling of serum cytokines for detection of pancreatic cancer. Cancer Biomark 2005;1(6):259-69.

10. Linkov F, Lisovich A, Yurkovetsky Z, Marrangoni A, Velikokhatnaya L, Nolen B, Winans M, Bigbee WL, Siegfried J, Lokshin AE, Ferris RL. Early detection of head and neck cancer: development of a nove screening tool using multiplexed immunobead-based biomarker profiling. Cancer Epidemiol Biomarkers Prev 2007;16(1):102-7.

11. Lambeck AJ, Crijns AP, Leffers N, Sluiter WJ, ten Hoor KA, Braid M, van der Zee AG, Daemen T, Nijman HW, Kast WM. Serum cytokine profiling as a diagnostic and prognostic tool in ovarian cancer: a potential role for interleukin 7. Clin Cancer Res 2007;13(8):2385-91.

12. Kornblau SM, Tibes R, Qiu YH, Chen W, Kantarjian HM, Andreeff M, Coombes KR, Mills GB. Functional proteomic profiling of AML predicts response and survival. Blood 2009;113(1):154-64.

13. Tomasson $M H$, Xiang Z, Walgren $R$, Zhao $Y$, Kasai $Y$, Miner T, Ries $\mathrm{RE}$, Lubman O, Fremont DH, McLellan MD, Payton JE, Westervelt $\mathrm{P}$, DiPersio JF, Link DC, Walter MJ, Graubert TA, Watson M, Baty J, Heath S, Shannon WD, Nagarajan R, Bloomfield CD, Mardis ER, Wilson RK Ley TJ. Somatic mutations and germline sequence variants in the expressed tyrosine kinase genes of patients with de novo acute myeloid leukemia. Blood 2008;111(9):4797-808.

14. Loriaux MM, Levine RL, Tyner JW, Fröhling S, Scholl C, Stoffregen EP, Wernig G, Erickson H, Eide CA, Berger R, Bernard OA, Griffin JD, Stone RM, Lee B, Meyerson M, Heinrich MC, Deininger MW, Gilliland DG, Druker BJ. High-throughput sequence analysis of the tyrosine kinome in acute myeloid leukemia. Blood 2008;111(9):4788-96.

15. Van Etten RA. Aberrant cytokine signaling in leukemia. Oncogene 2007;26(47):6738-49.
16. Hsu HC, Lee YM, Tsai WH, Jiang ML, Ho CH, Ho CK, Wang SY. Circulating levels of thrombopoietic and inflammatory cytokines in patients with acute myeloblastic leukemia and myelodysplastic syndrome. Oncology 2002;63(1):64-9.

17. Dokter WH, Tuyt L, Sierdsema SJ, Esselink MT, Vellenga E. The spontaneous expression of interleukin- 1 beta and interleukin- 6 is associated with spontaneous expression of AP-1 and NF-kappa B transcription factor in acute myeloblastic leukemia cells. Leukemia 1995;9(3):425-32.

18. Griffin JD, Rambaldi A, Vellenga E, Young DC, Ostapovicz D, Cannistra SA. Secretion of interleukin-1 by acute myeloblastic leukemia cells in vitro induces endothelial cells to secrete colony stimulating factors. Blood 1987;70(4):1218-21.

19. Birkenkamp KU, Esselink MT, Kruijer W, Vellenga E. Differential effects of interleukin-3 and interleukin-1 on the proliferation and interleukin- 6 protein secretion of acute myeloid leukemic cells; the involvement of ERK, p38 and STAT5. Eur Cytokine Netw 1999;10(4):479-90.

20. Bruserud $\varnothing$, Ryningen $A$, Olsens AM, Stordrange L, Øyan AM, Kalland $\mathrm{KH}, \mathrm{Gjertsen} \mathrm{BT}$. Subclassification of patients with acute myelogenous leukemia based on chemokine responsiveness and constitutive chemokine release by their leukemic cells. Haematologica 2007;92(3):332-41.

21. Krejsek J. Imunitní systém jako informační soustava. In: Krejsek J, Kopecky O. Klinická imunologie. Nukleus HK, 2004, p. 55-69.

22. Estrov Z, Roifman C, Mills G, Grunberger T, Gelfand EW, Freedman $\mathrm{MH}$. The regulatory role of interleukin 2-responsive $\mathrm{T}$ lymphocytes on human marrow granulopoiesis. Blood 1987;69(4):1161-6.

23. Ferrajoli A, Talpaz M, Zipf TF, Hirsch-Ginsberg C, Estey E, Wolpe SD, Estrov Z. Inhibition of acute myelogenous leukemia progenitor proliferation by macrophage inflammatory protein 1-alpha. Leukemia 1994;8(5):798-805.

24. Estrov Z, Kurzrock R, Estey E, Wetzler M, Ferrajoli A, Harris D, Blake M, Gutterman JU, Talpaz M. Inhibition of acute myelogenous leukemia blast proliferation by interleukin-1 (IL-1) receptor antagonist and soluble IL-1 receptors. Blood 1992;79(8):1938-45.

25. Estrov Z, Black RA, Sleath PR, Harris D, Van Q, LaPushin R, Estey EH, Talpaz M. Effect of interleukin-1 beta converting enzyme inhibitor on acute myelogenous leukemia progenitor proliferation. Blood 1995;86(12):4594-602.

26. Rombouts WJC, Löwenberg B, van Putten WLJ, Ploemacher RE. Improved prognostic significance of cytokine-induced proliferation in vitro in patients with de novo acute myelogenous leukemia of intermediate risk: impact of internal tandem duplications in the Flt3 gene. Leukemia 2001;15(7):1046-53.

27. Tsimberidou AM, Estey E, Wen S, Pierce S, Kantarjian H, Albitar M Kurzrock R. The prognostic significance of cytokine levels in newly diagnosed acute myeloid leukemia and high-risk myelodysplastic syndromes. Cancer 2008;113(7):1605-13.

28. Testa U, Riccioni R, Militi S, Coccia E, Stellacci E, Samoggia P, Latagliata R, Mariani G, Rossini A, Battistini A, Lo-Coco F, Peschle C. Elevated expression of IL-3Ralpha in acute myelogenous leukemia is associated with enhanced blast proliferation, increased cellularity, and poor prognosis. Blood 2002;100(8):2980-8.

29. Leverrier Y, Thomas J, Perkins GR, Mangeney M, Collins MK, Marvel J. In bone marrow derived Baf-3 cells, inhibition of apoptosis by IL-3 is mediated by two independent pathways. Oncogene 1997;14(4):42530.

30. Shimamura A, Ballif BA, Richards SA, Blenis J. Rsk1 mediates a MEKMAP kinase cell survival signal. Curr Biol 2000;10(3):127-35.

31. Deng X, Ruvolo P, Carr B, May WS Jr. Survival function of ERK $1 / 2$ as IL-3-activated, staurosporine resistant Bcl2 kinases. Proc Natl Acad Sci U S A 2000;97(4):1578-83.

32. del Peso L, González-García M, Page C, Herrera R, Nuñez G. Interleukin-3-induced phosphorylation of BAD through the protein kinase Akt. Science 1997;278(5338):687-9.

33. Mathieu AL, Gonin S, Leverrier Y, Blanquier B, Thomas J, Dantin C, Martin G, Baverel G, Marvel J. Activation of the phosphatidylinositol 3-kinase/Akt pathway protects against interleukin-3 starvation but not DNA damageinduced apoptosis. J Biol Chem 2001;276(14):10935-42.

34. Harada H, Becknell B, Wilm M, Mann M, Huang LJ, Taylor SS, Scott JD, Korsemeyer SJ. Phosphorylation and inactivation of BAD by mitochondria-anchored protein kinase A. Mol Cell 1999;3(4):413-22.

35. Dumon S, Santos SC, Debierre-Grockiego F, Gouilleux-Gruart V, Cocault L, Boucheron C, Mollat P, Gisselbrecht S, Gouilleux F. IL-3 
dependent regulation of $\mathrm{BCl}-\mathrm{XL}$ gene expression by STAT5 in bone marrow derived cell line. Oncogene 1999;18(29):4191-9.

36. Schepers H, van Gosliga D, Wierenga ATJ, Eggen BJL, Schuringa JJ, Vellenga E. STAT5 is required for long-term maintenance of normal and leukemic human stem/progenitor cells. Blood 2007;110(8):28808.

37. Kornblau SM, Womble M, Qiu YH, Jackson CE, Chen W, Konopleva M, Estey EH, Andreeff M. Simultaneous activation of multiple signal transduction pathways confers poor prognosis in acute myelogenous leukemia. Blood 2006;108(7):2358-65.

38. Hayakawa F, Towatari M, Kiyoi H, Tanimoto M, Kitamura T, Saito H, Naoe T. Tandem-duplicated Flt3 constitutively activates STAT5 and MAP kinase and introduces autonomous cell growth in IL-3dependent cell lines. Oncogene 2000;19(5):624-31.

39. Rocnik JL, Okabe R, Yu JC, Lee BH, Giese N, Schenkein DP, Gilliland DG. Roles of tyrosine 589 and 591 in STAT5 activation and transformation mediated by FLT3-ITD. Blood2006;108(4):1339-45.

40. Yoshimoto G, Miyamoto T, Jabbarzadeh-Tabrizi S, lino T, Rocnik JL, Kikushige Y, Mori Y, Shima T, Iwasaki H, Takenaka K, Nagafuji K, Mizuno S, Niiro H, Gilliland DG, Akashi K. FLT3-ITD up-regulates MCL1 to promote survival of stem cells in acute myeloid leukemia via FLT3-ITD-specific STAT5 activation. Blood 2009;114(24):5034-43.

41. Horita M, Andreu EJ, Benito A, Arbona C, Sanz C, Benet I, Prosper F, Fernandez-Luna JL. Blockade of the Bcr-Abl Kinase Activity Induces Apoptosis of Chronic Myelogenous Leukemia Cells by Suppressing Signal Transducer and Activator of Transcription 5-dependent Expression of BCl-xL. J Exp Med 2000;191(6):977-84.

42. Fajtova M, Babusikova O. Immunophenotype characterization of hematopoietic stem cells, progenitor cells restricted to myeloid lineage and their leukemia counterparts. Neoplasma 2010;57(5):392-400.

43. Heuser M, Sly LM, Argiropoulos B, Kuchenbauer F, Lai C, Weng A, Leung $M$, Lin G, Brookes C, Fung S, Valk PJ, Delwel R, Löwenberg B, Krystal G, Humphries RK. Modeling the functional heterogeneity of leukemia stem cells: role of STAT5 in leukemia stem cell self-renewal. Blood 2009;114(19):3983-93.

44. Gündogdu MS, Liu H, Metzdorf D, Hildebrand D, Aigner M, Aktories K, Heeg K, Kubatzky KF. The haematopoietic GTPase RhoH modulates IL3 signalling through regulation of STAT activity and IL3 receptor expression. Molecular Cancer 2010;9:225.

45. Iwasaki T, Katsumi A, Kiyoi H, Tanizaki R, Ishikawa $Y$, Ozeki K, Kobayashi M, Abe A, Matsushita T, Wantabe T, Amano M, Kojima T, Kaibuchi K, Naoe T. Prognostic implication and biological roles of $\mathrm{RhoH}$ in acute myeloid leukaemia. Eur J Haematol 2008;81(6):454-60.

46. Preti HA, Cabanillas F, Talpaz M, Tucker SL, Seymour JF, Kurzrock R. Prognostic value of serum interleukin-6 in diffuse large-cell lymphoma. Ann Intern Med 1997;127(3):186-94.

47. Fayad L, Keating MJ, Reuben JM, O'Brien S, Lee BN, Lerner S, Kurzrock R. Interleukin- 6 and interleukin-10 levels in chronic lymphocytic leukemia: correlation with phenotypic characteristics and outcome. Blood 2001;97(1):256-63.

48. Dokter WH, Tuyt L, Sierdsema SJ, Esselink MT, Vellenga E. The spontaneous expression of interleukin-1 beta and interleukin- 6 is as sociated with spontaneous expression of AP-1 and NF-kappa B transcription factor in acute myeloblastic leukemia cells. Leukemia 1995;9(3):425-32.

49. Schindler C, Darnell JE Jr. Transcriptional responses to polypeptide ligands: the JAK-STAT pathway. Annu Rev Biochem 1995;64:621-51.

50. Kim H, Baumann H. Dual signaling role of the protein tyrosine phosphatase SHP- 2 in regulating expression of acute-phase plasma proteins by interleukin- 6 cytokine receptors in hepatic cells. MolCell Biol 1999;19(8):5326-38.

51. Nishida K, Yoshida Y, Itoh M, Fukada T, Ohtani T, Shirogane T, Atsumi T, Takahashi-Tezuka M, Ishihara K, Hibi M, Hirano T. Gab-family adapter proteins act downstream of cytokine and growth factor receptors and T- and B-cell antigen receptors. Blood 1999;93(6):1809-16.

52. Chung TD, Yu JJ, Kong TA, Spiotto MT, Lin JM. Interleukin- 6 activates phosphatidylinositol-3 kinase, which inhibits apoptosis in human prostate cancer cell lines. Prostate 2000;42(1):1-7.

53. Fukada T, Ohtani T, Yoshida Y, Shirogane T, Nishida K, Nakajima K, Hibi $M$, Hirano T. STAT3 orchestrates contradictory signals in cytokineinduced G1 to S cell-cycle transition. EMBO J 1998;17(22):6670-7.

54. Gouilleux-Gruart V, Gouilleux F, Desaint C, Claisse JF, Capiod JC, Delobel J, Weber-Nordt R, Dusanter-Fourt I, Dreyfus F, Groner B, Prin L. STAT-related transcription factors are constitutively activat- ed in peripheral blood cells from acute leukemia patients. Blood 1996;87(5):1692-7.

55. Schuringa JJ, Wierenga AT, Kruijer W, Vellenga E. Constitutive stat3, tyr705, and ser727 phosphorylation in acute myeloid leukemia cells caused by the autocrine secretion of interleukin-6. Blood 2000;95(12):3765-70.

56. Tessier $\mathrm{N}$, Hoang $\mathrm{T}$. Transforming growth factor beta inhibits the proliferation of the blast cells of acute myeloblastic leukemia. Blood 1988;72(1):159-64.

57. Batard P, Monier MN, Fortunel N, Ducos K, Sansilvestri-Morel P, Phan T, Hatzfeld A, Hatzfeld JA. TGF-(beta)1 maintains hematopoietic immaturity by a reversible negative control of cell cycle and induces CD34 antigen up-modulation. J Cell Sci 2000;113:383-90.

58. Massagué J. TGF-beta signal transduction. Annu Rev Biochem 1998;67:753-91.

59. Derynck R, Zhang Y, Feng XH. Smads: transcriptional activators of TGF-beta responses. Cell 1998;95(6):737-40.

60. Wierenga ATJ, Schuringa JJ, Eggen BJL, Kruijer W, Vellenga E. Downregulation of IL-6-induced STAT3 tyrosine phosphorylation by TGF- $ß 1$ is mediated by caspase-dependent and -independent processes. Leukemia 2002;16(4):675-82.

61. Mantovani A. The chemokine system: redundancy for robust outputs. Immunol Today 1999;20(6):254-7.

62. Bendall L. Chemokines and their receptors in disease. Histol Histopathol 2005;20(3):907-26.

63. Tanaka T, Bai Z, Srinoulprasert Y, Yang BG, Hayasaka H, Miyasaka $M$. Chemokines in tumor progression and metastasis. Cancer Sci 2005;96(6):317-22.

64. Balkwill F. Cancer and the chemokine network. Nat Rev Cancer 2004;4(7):540-50

65. Rosenkilde MM, Schwartz TW. The chemokine system - a major regulator of angiogenesis in health and disease. APMIS 2004;112(78):481-95.

66. Faaij CM, Willemze AJ, Révész T, Balzarolo $M$, Tensen CP, Hoogeboom $M$, Vermeer $M H$, van Wering $E$, Zwaan CM, Kaspers GJ, Story C, van Halteren AG, Vossen JM, Egeler RM, van Tol MJ, Annels NE. Chemokine/chemokine receptor interactions in extramedullary leukemia of skin in childhood AML: differential roles for CCR2, CCR5, CXCR4 and CXCR7. Pediatr Blood Cancer 2010;55(2):344-8.

67. Kittang AO, Hatfield K, Sand K, Reikvam H, Bruserud Ø. The chemokine network in acute myelogenous leukemia: molecular mechanisms involved in leukemogenesis and therapeutic implications. Curr Top Microbiol Immunol 2010;341:149-72.

68. Hatfield KJ, Bedringsaas SL, Ryningen A, Gjertsen BT, Bruserud Ø. Hypoxia increases HIF-1a expression and constitutive cytokine release by primary human acute myeliod leukemia cells. European cytokine network 2010;21(3):154-64.

69. Reikvam H, Hatfield KJ, Lassalle P, Kittang AO, Ersaver E, Bruserud Ø. Targeting the angiopoietin (Ang)/Tie-2 pathway in the crosstalk between acute myeloid leukemia and endothelial cells: studies of Tie-2 blocking antibodies, exogenous Ang- 2 and inhibition of constitutive agonistic Ang-1 release. Expert Opin Investig Drugs 2010;19(2):16983.

70. Hatfield KJ, Reikvam H, Bruserud Ø. The crosstalk between the matrix metalloprotease system and the chemokine network in acute myeloid leukemia. Curr Med Chem 2010;17(36):4448-61.

71. Woerner BM, Warrington NM, Kung AL, Perry A, Rubin JB. Widespread CXCR4 activation in astrocytomas revealed by phospho-CXCR4-specific antibodies. Cancer Res. 2005;65(24):11392-9.

72. Tilton B, Ho L, Oberlin E, Loetscher P, Baleux F, Clark-Lewis I, Thelen $M$. Signal transduction by CXC chemokine receptor 4 . Stromal cellderived factor 1 stimulates prolonged protein kinase $B$ and extracellular signal-regulated kinase 2 activation in T lymphocytes. J Exp Med. 2000;192(3):313-24.

73. Datta SR, Brunet A, Greenberg ME. Cellular survival: a play in three Akts. Genes Dev 1999;13(22):2905-27.

74. Nebreda AR, Gavin AC. Perspectives: signal transduction. Cell survival demands some Rsk. Science 1999;286(5443):1309-10.

75. Spoo AC, Lübbert M, Wierda WG, Burger JA. CXCR4 is a prognostic marker in acute myelogenous leukemia. Blood 2007;109(2):785-91.

76. Konoplev S, Rassidakis GZ, Estey E, Kantarijan H, Liakou Cl, Juany X Andreeff M, Konopleva M, Medeiros LI. Overexpression of CXCR4 predicts adverse overall and event-free survival in patients with unmutated FLT3 acute myeloid leukemia with normal karyotype. Cancer 2007;109(6):1152-6. 
77. Rombouts EJ, Pavic B, Lowenberg B, Ploemacher RE. Relation between CXCR-4 expression, Flt3 mutations, and unfavorable prognosis of adult acute myeloid leukemia. Blood 2004;104(2):550-7.

78. Zheng F, Li H, Du W, Huang S. Role of hERG1 K(+) channels in leukemia cells as a positive regulator in SDF-1a-induced proliferation. Hematology 2011;16(3):177-84.

79. Devine SM, Flomenberg N, Vesole DH, Liesveld J, Weisdorf D, Bade K, Calandra G, DiPersio JF. Rapid mobilization of CD34_cells following administration of the CXCR4 antagonist AMD3100 to patients with multiple myeloma and non-Hodgkin's lymphoma. J Clin Oncol 2004;22(6):1095-102.

80. Flomenberg N, Devine SM, DiPersio JF, Liesveld J, McCarty JM, Rowley SD, Vesole DH, Badel K, Calandra G. The use of AMD3100 plus G-CSF for autologous hematopoietic progenitor cell mobilization is superior to G-CSF alone. Blood 2005;106(5):1867-74.

81. Zeng Z, Samudio IJ, Munsell M, An J, Huang Z, Estey E, Andreeff M, Konopleva M. Inhibition of CXCR4 with the novel RCP 168 peptide overcomes stroma-mediated chemoresistance in chronic and acute leukemias. Mol Cancor Ther 2006;5(12):3113-21.

82. Zeng Z, Shi YX, Samudio IJ, Wang R, Ling X, Frolova O, Levis M, Rubin JB, Negrin RR, Estey EH, Konoplev S, Andreeff M, Konopleva $M$. Targeting the leukemia microenvironment by CXCR4 inhibition overcomes resistance to kinase inhibitors and chemotherapy in AML. Blood 2009;113(24):6215-24.

83. Ma $Q$, Jones $D$, Springer TA. The chemokine receptor CXCR4 is required for the retention of $B$ lineage and granulocytic precursors within the bone marrow microenvironment. Immunity 1999;10(4):463-71.

84. Niedermeier M, Hennessy BT, Knight ZA, Henneberg M, Hu J, Kurtova AV, Wierda WG, Keating MJ, Shokat KM, Burger JA. Isoformselective phosphoinositide 3 '-kinase inhibitors inhibit CXCR4 signaling and overcome stromal cell-mediated drug resistance in chronic lymphocytic leukemia: a novel therapeutic approach. Blood 2009;113(22):5549-57.

85. Reikvam H, Mosevoll KA, Melve GK, Günther CC, Sjo M, Bentsen PT, Bruserud $\varnothing$. The Pretransplantation Serum Cytokine Profile in Allogenic Stem Cell Recipients Differs from Healthy Individuals, and Various Profiles are Associated with Different Risks of Posttransplantation Complications. Biology of Blood and Marrow Transplantation 2012;18(2):190-9.

86. Ersaver E, Melve GK, Bruserud $\varnothing$. Future perspectives: should Th17 cells be considered as a possible therapeutic target in acute myeloid leukemia patients receiving allogenic stem cell transplantation? Cancer Immunol Immunother 2011;60:1669-81.

87. Cosmi L, De Palma R, Santarlasci V, Maggi L, Capone M, Frosal F, Rodolico G, Querci V, Abbate G, Angeli R, Berrino L, Fambrini M, Caproni M, Tonelli F, Lazzeri E, Parronchi P, Liotta F, Maggi E, Romagnani S, Annunziato F. Human interleukin 17-producing cells originate from a CD161+CD4+ T cell precursor. J Exp Med 2008;205(8):1903-16

88. Valmori D, Raffin C, Raimbaud I, Ayyoub M. Human RORgammat+ TH17 cells preferentially differentiate from naive FOXP3+ Treg in the presence of lineage-specific polarizing factors. Proc Natl Acad Sci USA 2010;107(45):19402-7.

89. Acosta-Rodriguez EV, Napolitani G, Lanzavecchia A, Sallusto F. Interleukins 1 beta and 6 but not transforming growth factor-beta are essential for the differentiation of interleukin 17-producing human T helper cells. Nat Immunol 2007;8(9):942-9.

90. Santarlasci V, Maggi L, Capone M, Frosali F, Querci V, De Palma R, Liotta F, Cosmi L, Maggi E, Romagnani S, Annunziato F. TGF-beta indirectly favors the development of human Th17 cells by inhibiting Th1 cells. Eur J Immunol 2009;39(1):207-15.

91. Bruserud $\varnothing$. Acute myelogenous leukemia blasts as accessory cells during T lymphocyte activation: possible implications for future therapeutic strategies. Leukemia 1999;13(8):1175-87.

92. Bruserud $\varnothing$, Kittang AO. The chemokine system in experimental and clinical hematology. Curr Top Microbiol Immunol 2010;341:3-12.

93. Ersvaer E, Liseth K, Skavland J, Gjertsen BT, Bruserud $\varnothing$. Intensive chemotherapy for acute myeloid leukemia differentially affects circulating TC1, TH1, TH17 and TREG cells. BMC Immunol 2010;11:38.

94. Wu C, Wang S, Wang F, Chen Q, Peng S, Zhang Y, Qian J, Jin J, Xu $\mathrm{H}$. Increased frequencies of T helper type 17 cells in the peripheral blood of patients with acute myeloid leukaemia. Clin Exp Immunol 2009;158(2):199-204.
95. Szczepanski MJ, Szajnik M, Czystowska M, Mandapathil M, Strauss L, Welsh A, Foon KA, Whiteside TL, Boyiadzis M. Increased frequency and suppression by regulatory $T$ cells in patients with acute myelogenous leukemia. Clin Cancer Res 2009;15(10):3325-32.

96. Burnett A, Wetzler M, Löwenberg B. Therapeutic advances in acute myeloid leukemia. J Clin Oncol 2011;29(5):487-94.

97. Park H, Li Z, Yang XO, Chang SH, Nurieva R, Wang YH, Wang Y, Hood $\mathrm{L}$, Zhu Z, Tian Q, Dong C. A distinct lineage of CD4 T cells regulates tissue inflammation by producing interleukin 17. Nat Immunol 2005;6(11):1133-41.

98. Carvalho A, Cunha C, Di lanni M, Pitzurra L, Aloisi T, Falzetti F, Carotti A, Bistoni F, Aversa F, Romani L. Prognostic significance of genetic variants in the IL-23/Th17 pathway for the outcome of T cell-depleted allogeneic stem cell transplantation. Bone Marrow Transplant 2010;45(11):1645-52.

99. Liseth K, Sjo M, Paulsen K, Bruserud O, Ersvaer E. Early pre-engraftment, functional, in vitro responsiveness of T lymphocytes in allotransplanted, acute leukemia patients: proliferation and release of a broad profile of cytokines, possibly predictive of graft-versus-host disease. Eur Cytokine Netw 2010;21(1):40-9.

100. Zhao XY, Xu LL, Lu SY, Huang XJ. IL-17-producing T cells contribute to acute graft-versus-host disease in patients undergoing unmanipulated blood and marrow transplantation. Eur J Immunol 2011;41(2):514-26

101. Iclozan C, Yu Y, Liu C, Liang Y, Yi T, Anaseti C, Yu XZ. T helper17 cells are sufficient but not necessary to induce acute graft-versus-host disease. Biol Blood Marrow Transplant 2010;16(2):170-8.

102. Yi T, ChenY, Wang L, Du G, Huang D, Zhao D, Johnston H, Young J, Todorov I, Umetsu DT, Chen L, Iwakura Y, Kandeel F, Forman S, Zeng D. Reciprocal differentiation and tissue-specific pathogenesis of Th1, Th2, and Th17 cells in graft-versus-host disease. Blood 2009;114(14):3101-12

103. Singh SP, Zhang HH, Foley JF, Hedrick MN, Farber JM. Human T cells that are able to produce IL-17 express the chemokine receptor CCR6. J Immunol 2008;180(1):214-21.

104. Lotem J, Sachs L. Control of apoptosis in hematopoiesis and leukemia by cytokines, tumor suppressor and oncogenes. Leukemia 1996;10(6):925-31.

105. Buyse M, Squifflet P, Lange BJ, Alonzo TA, Larson RA, Kolitz JE, George SL, Bloomfield CD, Castaigne S, Chevret S, Blaise D, Maraninchi D, Lucchesi KJ, Burzykowski T. Individual patient data meta-analysis of randomized trials evaluating IL-2 monotherapy as remission maintenance therapy in acute myeloid leukemia. Blood 2011;117(26):7007-13.

106. Brune M, Castaigne S, Catalano J, Gehlsen K, Ho AD, Hofmann WK, Hogge DE, Nilsson B, Or R, Romero Al, Rowe JM, Simonsson $B$, Spearing R, Stadtmauer EA, Szer J, Wallhult E, Hellstrand K. Improved leukemia-free survival after postconsolidation immunotherapy with histamine dihydrochloride and interleukin-2 in acute myeloid leukemia: results of a randomized phase 3 trial. Blood 2006;108(1):88-96.

107. Buyse M, Squifflet P, Lucchesi KJ, Brune ML, Castaigne S, Rowe JM. Assessment of the consistency and of results from a multicenter trial of remission maintenance therapy for acute myeloid leukemia. Trials 2011;12:86.

108. Firas AS, Demeckova E, Bojtarova E, Czako B, Hrubisko M, Mistrik $M$. Isolated extra-medullary relapse of acute leukemia following allogeneic bone marrow transplantation. Bratisl Lek Listy 2008;109(8):358-61.

109. Kaushansky K. Signal transduction pathways. In: Kaushansky K, Lichmann MA, Beutler E, Kipps TJ, Seligsohn U, Prchal JT. Williams Hematology, Eighth Edition, McGraw-Hill, 2010. p. 183-9.

110. Toffalini F, Demoulin J-B. New insights into the mechanisms of hematopoietic cell transformation by activated receptor tyrosine kinases. Blood 2010;116(14):2429-37.

111. Faderl S, Pal A, Bornmann W, Albitar M, Maxwell D, Van Q, Peng Z, Harris D, Liu Z, Hazan-Halevy I, Kantarjian HM, Estrov Z. Kit Inhibitor ApcK1 10 Induces Apoptosis and Inhibits Proliferation of Acute Myeloid Leukemia Cells. Cancer Res 2009;69(9):3910-7.

112. Yang X, Liu L, Sternberg D, Tang L, Galinsky I, DeAngelo D, Stone R. The FLT3 Internal Tandem Duplication Mutation Prevents Apoptosis in Interleukin-3-Deprived BaF3 Cells Due to Protein Kinase A and Ribosomal S6 Kinase 1-Mediated BAD Phosphorylation at Serine 112. Cancer Res 2005;65(16):7338-47. 
113. Paschka P, Marcucci G, Ruppert AS, Mròzek K, Chen H, Kittles RA, Vukosavljevic T, Perrotti D, Vardiman JW, Carroll AJ, Kolitz JE, Larson RA, Bloomfeld CD. Adverse prognostic significance of c-kit in adult acute myeloid leukemia with inv(16) and $t(8,21)$ : a Cancer and Leukemia Group B Study. J. Clin Oncol 2006;24(24):3904-11.
114. Kindler T, Lipka DB, Fischer T. FLT3 as a therapeutic target in AML: still challenging after all these years. Blood 2010;116(24):5089-102.

115. Meyers CA, Albitar M, Estey E. Cognitive Impairment, Fatigue, and Cytokine Levels in Patients with Acute Myelogenous Leukemia or Myelodysplastic Syndrome. Cancer 2005;104(4):788-93. 